\title{
Heart and lung transplantation in patients with end stage lung disease
}

\author{
ANDREA PENKETH, TIM HIGENBOTTAM, MOHSIN HAKIM, JOHN WALLWORK
}

\begin{abstract}
Combined heart and lung transplantation was used to treat seven patients with end stage lung disease. All were severely disabled, and their disease carried a poor prognosis. Six patients were well four to 33 months after transplantation. One patient died after 44 days from a primary cytomegalovirus pneumonia transmitted from the donor. All the survivors had normal exercise tolerance and greatly improved lung function.

It is concluded that heart and lung transplantation is a suitable treatment for selected patients with end stage chronic lung disease.
\end{abstract}

\section{Introduction}

Human heart and lung transplantation was first reported in $1982 .{ }^{1}$ The patients had severe pulmonary vascular disease, either primary or secondary to cardiac disease. ${ }^{2}{ }^{3}$ Despite the long term problems in diagnosing rejection or infection in the transplanted lung,,$^{2-4}$ this treatment may be beneficial for patients with other lung diseases. We report our early experience of combined heart and lung transplantation in seven patients who had end stage chronic lung disease.

\section{Methods}

Between November 1982 and September 1986, 199 patients were referred for heart and lung transplantation. Of these, 53 patients were accepted on to a waiting list and 19 received a transplant. Seven of these patients had chronic lung disease. All 199 patients were severely disabled. Those who were selected for transplantation had a poor prognosis, and no further conventional treatment could be offered to them. Patients were accepted for operation if they were under 49 years of age and free of systemic illness or secondary organ dysfunction. Other contraindications were previous extensive cardiac or thoracic surgery, ${ }^{3}$ the presence of systemic infections, or concurrent treatment with corticosteroids.

Table I gives the ages of the seven patients (range 20 to 43 years) and the diagnoses. They had been ill for from two to nine years. Two were confined to bed in hospital, and the others required frequent treatment as inpatients. As a group the maximum reported exercise tolerance was walking a distance of 100 yards $(91.4 \mathrm{~m})$ on the flat at their own pace (table I).

TABLE I-Details of heart and lung transplant recipients before operation

\begin{tabular}{|c|c|c|c|c|c|}
\hline $\begin{array}{l}\text { Patient } \\
\text { No }\end{array}$ & $\begin{array}{c}\text { Age } \\
\text { (years) }\end{array}$ & Sex & Diagnosis & $\begin{array}{l}\text { Secondary right } \\
\text { heart failure }\end{array}$ & $\begin{array}{l}\text { Maximum exercise } \\
\text { tolerance }\end{array}$ \\
\hline 1 & 37 & $\mathbf{F}$ & $\begin{array}{l}\text { Cryptogenic fibrosing } \\
\text { alveolitis }\end{array}$ & Yes & Confined to bed \\
\hline 2 & 20 & $\mathbf{F}$ & Cystic fibrosis & Yes & 30 yards $(27 \cdot 4 \mathrm{~m})$ \\
\hline 3 & 42 & $\mathbf{F}$ & Emphysema & Yes & Confined to bed \\
\hline 4 & 35 & $\mathbf{F}$ & Sarcoidosis & Yes & 30 yards $(27 \cdot 4 \mathrm{~m})$ \\
\hline 5 & 47 & $\mathbf{F}$ & Emphysema & Yes & 40 yards $(36.6 \mathrm{~m})$ \\
\hline 6 & 23 & $\mathbf{M}$ & Histiocytosis X & No & 20 yards $(18 \cdot 2 \mathrm{~m})$ \\
\hline 7 & 43 & $\mathbf{M}$ & Bronchiectasis & Yes & 100 yards $(91.4 \mathrm{~m})$ \\
\hline
\end{tabular}

Only the patient with cystic fibrosis had infected sputum at the time of the operation. The organism consistently cultured from the sputum was Pseudomonas aeruginosa. The patients with cryptogenic fibrosing alveolitis, histiocytosis $\mathrm{X}$, and sarcoidosis had been treated with corticosteroids and azathioprine in the past. All patients with airways obstruction were treated with inhaled bronchodilator (salbutamol) and inhaled topical steroid (beclomethasone diproprionate). 
The diagnoses of cryptogenic fibrosing alveolitis and histiocytosis $\mathrm{X}$ were made by open lung biopsy at the referring hospital. Sarcoidosis was diagnosed from a lymph node biopsy specimen. The diagnosis in the other patients was confirmed from histology of the lungs after transplantation.

The operation (fig 1), selection of donors, and perioperative care have been described elsewhere. ${ }^{5}$ Immunosuppressive treatment was given with cyclosporin and prednisolone to the first patient; the other six received cyclosporin and azathioprine. Pulmonary function was recorded before and after the operation, at monthly intervals for six months, and every five months thereafter. A dry wedge spirometer was used to record forced expired volume in one second and forced vital capacity (Vitalograph, Buckingham, England). Single breath gas transfer for carbon monoxide was measured with Transfer Test equipment (P K Morgan, Chatham, Kent, England). ${ }^{6}$ Static lung volumes were recorded in a whole body plethysmograph (P K Morgan, Chatham, Kent, England). ${ }^{?}$

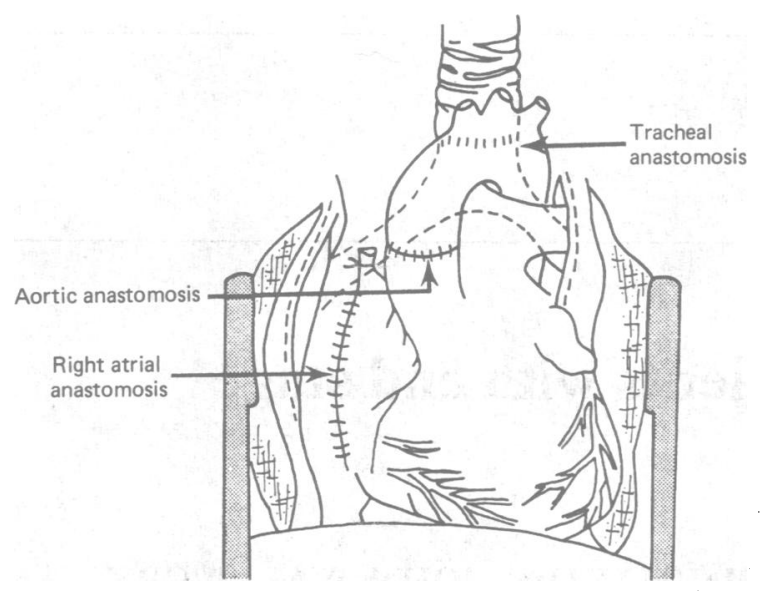

FIG 1-Diagram of heart and lung transplantation, showing the tracheal anastomosis about $1.5 \mathrm{~cm}$ above the carina and the atrial and aortic anastomoses between the recipient's remaining right atrium and ascending aorta to the donor heart. The phrenic nerves are carefully preserved within a pedicle of pericardium.

\section{Results}

All the patients survived the operation. One died after 44 days from cytomegalovirus pneumonitis diagnosed after a transbronchial lung biopsy. All of the other patients are alive four to 33 months after their operation.

Table II lists the postoperative complications. Only one patient required

TABLE II-Postoperative course of seven patients with primary lung disease who had heart and lung transplantation

\begin{tabular}{|c|c|c|c|c|c|}
\hline $\begin{array}{l}\text { Patient } \\
\text { No }\end{array}$ & $\begin{array}{l}\text { Length of } \\
\text { hospital stay } \\
\text { (days) }\end{array}$ & $\begin{array}{l}\text { Complications } \\
\text { of operation }\end{array}$ & $\begin{array}{l}\text { Rejection } \\
\text { episodes }\end{array}$ & $\begin{array}{l}\text { Infection } \\
\text { episodes }\end{array}$ & $\begin{array}{l}\text { Survival to } \\
\text { 1 Jan } 1987 \\
\text { (months) }\end{array}$ \\
\hline 1 & 78 & None & One & $\begin{array}{l}\text { Primary cytomegalo- } \\
\text { virus infection; } \\
\text { reactivated } \\
\text { tuberculosis; } \\
\text { RTI }\end{array}$ & 33 \\
\hline 2 & 36 & None & None & RTI & 15 \\
\hline 3 & 84 & $\begin{array}{l}\text { Bleeding from } \\
\text { SVC site and } \\
\text { difficulty in } \\
\text { weaning from } \\
\text { ventilator; } \\
\text { tracheostomy; } \\
\text { chest wall } \\
\text { deformity }\end{array}$ & None & None & 15 \\
\hline 4 & 44 & None & None & $\begin{array}{l}\text { Cytomegalovirus } \\
\text { pneumonitis }\end{array}$ & Died day 44 \\
\hline $\begin{array}{l}5 \\
6\end{array}$ & $\begin{array}{l}36 \\
42\end{array}$ & $\begin{array}{l}\text { None } \\
\text { None }\end{array}$ & $\begin{array}{l}\text { None } \\
\text { None }\end{array}$ & $\begin{array}{l}\text { RTI } \\
\text { None }\end{array}$ & $\begin{array}{r}7 \\
7\end{array}$ \\
\hline 7 & 62 & Right chylothorax & & $\begin{array}{l}\text { Primary cytomegalo- } \\
\text { virus infection }\end{array}$ & 4 \\
\hline
\end{tabular}

$\mathrm{RTI}=$ Respiratory tract infection with fever, productive cough, identifiable pathogens in sputum and a response to antibiotics. SVC=Superior vena cava. assisted ventilation for more than 36 hours after the operation (patient 3 ), largely because of chest wall deformity, pectus carinatum, and kyphoscoliosis. Patient 7 had a recurrent chylous effusion that required continuous pleural drainage for three weeks.

Patient 1 survived a severe primary cytomegalovirus infection of the small bowel that was diagnosed serologically and by culture of a gastric mucosal biopsy specimen. Patient 7 had a mild febrile illness within a week of the operation which was associated with a rise in specific IgM to cytomegalovirus but had no other disorder. His fever resolved after treatment with hyperimmune globulin. These two patients and the patient who died were seronegative for cytomegalovirus before the operation but received organs from seropositive donors. Another such patient suffered no ill effects and remained seronegative for cytomegalovirus.

Three patients $(1,2$, and 5$)$ had a bacterial bronchial infection, one at seven days, one at three months, and patient 1 had two infections at six and nine months. They all had a cough, sputum, and fever, and no radiological abnormality. The diagnosis was made by sputum culture, which showed Streptococcus pneumoniae in two and Haemophilus influenzae in the other. They responded to oral amoxycillin $500 \mathrm{mg}$ three times a day. During the illness small changes in forced expired volume in one second and forced vital capacity occurred, but there was little change in gas transfer for carbon monoxide or total lung capacity. A tuberculous empyema developed in patient 1 , who had been treated for tuberculosis in 1971. This responded to a standard course of rifampicin, isoniazid, and ethambutol.

Patient 1 also had an episode of rejection which coincided with the start of antituberculous chemotherapy. The diagnosis was made clinically. ${ }^{38}$ The patient complained of increasing breathlessness; there were no interstitial shadows in the radiograph, but she had widespread late inspiratory crackles on auscultation of the chest. In addition, the forced expired volume in one second and forced vital capacity fell. This episode responded to a three day course of intravenous methylprednisolone $(3 \mathrm{~g})$ and a temporary increase in the dose of cyclosporin (fig 2).

Lung function improved progressively in all six survivors (fig 3 ). Three returned to work four to six months after the operation, and the other three

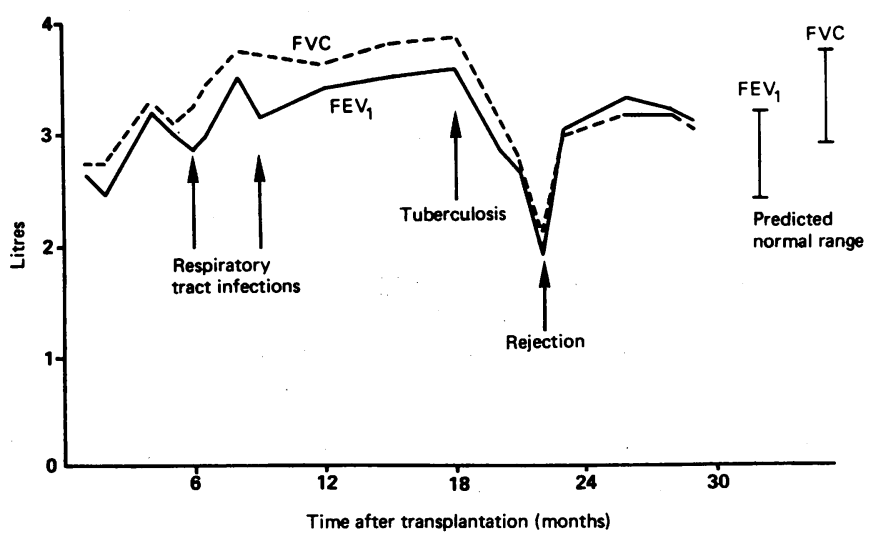

FIG 2-Forced expired volume in one second $\left(\mathrm{FEV}_{1}\right)$ and forced vital capacity (FVC) in patient 1 measured over 33 months; predicted values are shown by the lines and bars. Changes in dynamic lung volumes are shown at times of infections and during episode of rejection.

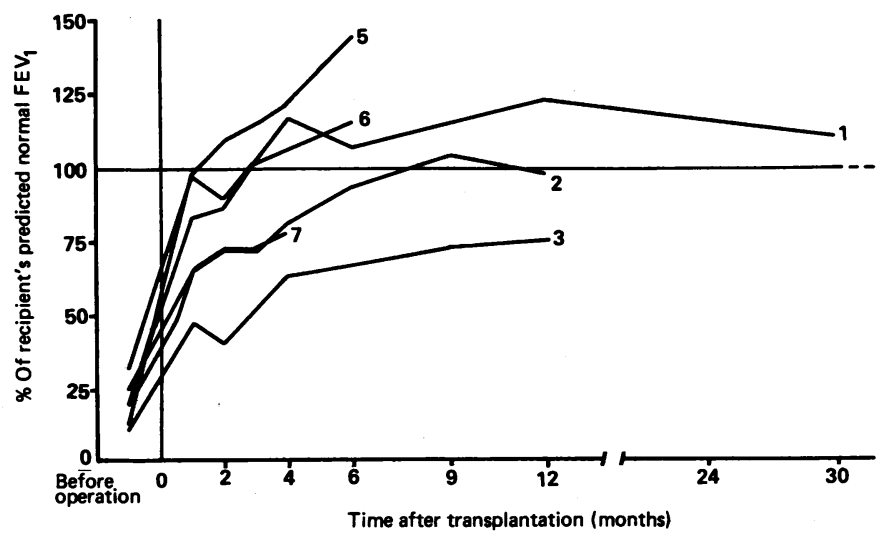

FIG 3-Forced expired volume in one second $\left(\mathrm{FEV}_{1}\right)$ as percentage of predicted for each surviving patient before operation and during months after operation. 
were fit to do so. Before transplantation all patients had reduced values of forced expired volume in one second of between $11 \%$ and $22 \%$ of those predicted. With the exception of patient 3 , who had a chest wall deformity, all patients achieved $80 \%$ of predicted values by four months and $100 \%$ by six months. The increase in forced expired volume in one second was greater than the increase in forced vital capacity, which, however, took about the same length of time to improve. Apart from patient 3 all other survivors achieved a total lung capacity of $90-100 \%$ of predicted values by four months. The gas transfer for carbon monoxide also rose to a range of $89-98 \%$ of predicted values by four months.

At six months all of the patients could walk any distance at a normal walking pace. The results of formal exercise tolerance tests will be reported later.

\section{Discussion}

Combined heart and lung transplantation was initially used to treat pulmonary vascular disease. Since 1984, 19 heart and lung transplants have been performed at this hospital, seven of them for chronic lung disease. Our limited experience with these seven patients indicates that with suitable selection this is a worthwhile treatment. With time lung function has returned to normal predicted values, and patients report normal exercise tolerance. In contrast to patients with pulmonary vascular disease our survivors have not developed obliterative bronchiolitis. ${ }^{38} \mathrm{~A}$ recent review places lung transplantation for lung disease in perspective. ${ }^{9}$ Success, however, has lagged behind that with other organs for various reasons.

Our major clinical problems have been cylumegalovirus infection and rejection. The cytomegalovirus infections were primary, occurring shortly after the operation, and are assumed to have been acquired by previously seronegative recipients from the donor. ${ }^{10}$ This has led to a change in practice. Donors are now serotyped for cytomegalovirus, and the recipient is matched. In future it may be possible to "vaccinate" the seronegative recipients for cytomegalovirus to extend the potential range of donors.

In one patient a serious rejection episode followed the start of antituberculous treatment. As antibiotics are known to reduce the efficacy of cyclosporin ${ }^{11}$ the event was expected. A full response to increased immunosuppression, including relief of symptoms, the disappearance of abnormal physical signs, and an increase in pulmonary function, was observed after 14 days of treatment.

Bacterial bronchitis occurred on three occasions but responded to treatment with conventional antibiotics, and there was no sustained loss of lung function. Three factors may have contributed to these infections: a reduction in the efficacy of the cough reflex, impaired mucociliary clearance, and interruption of the mucociliary "escalator" at the tracheal anastomosis. These patients can cough because the larynx and trachea are innervated. ${ }^{5}$ The airways below the anastomosis, however, are denervated, preventing the initiation of the cough reflex from the bronchial tree. Mucociliary clearance may also be impaired in these regions as a result of denervation, ${ }^{12}{ }^{13}$ although this has not yet been studied. The interruption of the mucociliary escalator at the tracheal anastomosis may also be important.

The size of the donor lungs and the recipient's thoracic cavity must be matched. If the donor lungs are too large atelectasis and right to left shunt may occur. ${ }^{4}$ We measure thoracic vertebral height and width of the rib cage in the chest radiograph. Three recipients had overinflated lungs, two of whom had emphysema and one of whom had histiocytosis X. All had a normal total lung capacity after operation (96-108\% of recipient values predicted by four months).

Patients with pulmonary vascular disease who undergo heart and lung transplantation have a restrictive ventilatory defect. ${ }^{14}$ This probably reflects changes in the mobility of the chest wall after median sternotomy, ${ }^{15}$ which is also seen in patients after coronary artery bypass grafting and which resolves with time. ${ }^{16}$ This effect was less obvious in our patients, in whom preoperative lung function was grossly reduced. All patients achieved a normal total lung capacity four months after the operation.

Combined heart and lung transplantation for lung disease may not be superior to transplantation of both lungs or of a single lung. ${ }^{17}$
It is easier to transplant the heart and lungs together. ${ }^{+}$But it is no longer thought that the transplanted heart offers a means of diagnosing rejection through an endomyocardial biopsy. ${ }^{18}$ The transplanted heart and lungs reject independently of one another. ${ }^{19}$

Single lung transplantation is valuable for fibrotic lung disease, ${ }^{20}$ but earlier experience with a wide range of lung disease was disappointing. ${ }^{21}$ This reflects the poorer healing of a bronchial anastomosis compared with a tracheal anastomosis, which has a better collateral blood supply. ${ }^{22}$ Patients who have suppurative lung disease will infect the transplanted single lung, and ventilation and perfusion mismatch may occur in emphysema. ${ }^{23}$ Our experience suggests that combined heart and lung transplantation should therefore be offered to these patients. Only patient 1 would have been suitable for single lung transplantation.

To gauge the potential recipient population we reviewed the mortality for England and Wales from these chronic lung diseases in patients between the ages of 10 and 49 years (table III). Cryptogenic

TABLE III-Deaths from respiratory disease in England and Wales for ages 10 to 49 years

\begin{tabular}{|c|c|c|c|c|c|c|}
\hline \multirow[b]{2}{*}{ Year } & \multicolumn{5}{|c|}{ Diagnosis } & \multirow{2}{*}{$\begin{array}{l}\text { Total No of } \\
\text { potential heart } \\
\text { and lung } \\
\text { transplant } \\
\text { recipients }\end{array}$} \\
\hline & $\begin{array}{l}\text { Cystic } \\
\text { fibrosis }\end{array}$ & Emphysema & Sarcoidosis & $\begin{array}{l}\text { Fibrosing } \\
\text { alveolitis }\end{array}$ & $\begin{array}{l}\text { Other lung } \\
\text { diseases }^{\star}\end{array}$ & \\
\hline 1979 & 81 & 36 & 20 & 13 & 13 & 163 \\
\hline 1980 & 88 & 29 & 15 & 20 & 17 & 169 \\
\hline 1981 & 87 & 26 & 14 & 9 & 27 & 163 \\
\hline 1982 & 55 & 29 & 24 & 15 & 22 & 145 \\
\hline 1983 & 101 & 26 & 22 & 13 & 19 & 181 \\
\hline 1984 & 92 & 32 & 27 & 21 & 13 & 185 \\
\hline
\end{tabular}

^Includes collagen vascular disorders and pulmonary eosinophilia.

fibrosing alveolitis is a disease of elderly people so that only a few are within our age range. Similarly, only a few patients die from sarcoidosis and other "granulomatous" lung diseases. Some patients under 49 years of age who die with emphysema will have $\alpha_{1}$ antitrypsin deficiency, ${ }^{24}$ although neither of our patients in this series had the condition. Theoretically, $\alpha_{1}$ antitrypsin deficient recipients may be prone to develop emphysema in the transplanted lungs during periods of pulmonary inflammation, ${ }^{25}$ such as might occur with episodes of infection or rejection.

More patients with cystic fibrosis than with other diseases are likely to benefit from combined heart and lung transplantation, particularly as most now survive until adult life. ${ }^{26}$ Selection is important; relative contraindications would be extrapulmonary disease-for example, insulin dependent diabetes mellitus, which occurs in $4 \%$ of patients, and liver disease with portal hypertension, which is present in $1 \% .{ }^{27}$ It is now possible, however, to combine transplantation of the liver with transplantation of heart and lungs. Extensive pleural fibrosis from surgical treatment of recurrent pneumothorax may be an important contraindication. Recurrent pneumothorax is common in the older patients with cystic fibrosis. ${ }^{28}$ Pulmonary infection in cystic fibrosis is not a problem since it is usually confined to the lungs. Pleural and systemic infections are rare. ${ }^{29}$ Transplantation offers the removal of the main source of sepsis. In our patient it was associated with an increase in body weight of $6 \mathrm{~kg}$ in the first 12 weeks. The presence of Aspergillus fumigatus is of concern as a possible opportunistic infection after transplantation. ${ }^{30}$

We conclude that probably about 100 patients a year with lung disease in England and Wales would benefit from combined heart and lung transplantation. This should not be too great a demand on donor resources but implies that several centres need to carry out this type of surgery. There is still the problem of diagnosis and treatment of rejection. ${ }^{3}$ Transbronchial lung biopsies may help to solve this, and our experience of this technique will be reported. In addition, there remain difficulties in using cyclosporin, particularly in determining adequate treatment for the patient and avoiding nephrotoxicity. ${ }^{31}$ Nevertheless, our limited experience of heart and 
lung transplantation is encouraging. This surgery offers a treatment for a wide range of end stage chronic lung disease.

We thank Mr Ben Milstein for editorial comments and criticisms; Ms Noreen Caine for the mortality statistics; Professor M Turner-Warwick, Dr J C Batten, Dr M E Hodson, Dr S W Clarke, Dr G M Jeremiah, Wing Commander W Hopkirk, and Dr M M Webb-Pearce for referring patients; the staff at the hospitals from which we obtained donor organs for their help; and Miss K Lightfoot for preparing the manuscript.

\section{References}

1 Reitz BA, Wallwork J, Hunt SA, et al. Heart-lung transplantation: a successful therapy for patients with pulmonary vascular disease. $N$ Engl f Med 1982;306:557-63.

2 Jamieson SW, Baldwin J, Reitz BA, et al. Combined heart and lung transplantation. Lance 1983;i:1130-2.

3 BurkeCM, Theodore J, Baldwin JC, et al. Twenty-eight cases of human heart-lung transplantation. Lancet 1986; i:517-9.

4 Reitz BA. Heart-lung transplantation: a review. Heart Transplantation 1982;1:291-7.

5 Jamieson SW, Stinson EB, Oger PE, Baldwin JC, Shumway NE. Operative techniques for heart lung transplantation. 7 Thorac Cardiovasc Surg 1984;87:930-5.

6 Meade F, Saunders MJ, Hyett F, Reynolds JA, Pearl N, Cotes JE. Automatic measurement of lung function. Lancet 1965;ii:573-5.

7 DuBois AB, Botelho SY, Bedell GN, Marshall R, Comroe JH. A rapid plethysmographic method for measuring thoracic gas volume. $\mathcal{F}$ Clin Invest 1956;35:322-6.

8 Burke CM, Theodore J, Dawkings KD, et al. Post-transplant obliterative bronchiolitis and other late lung sequelae in human heart-lung transplantation. Chest 1984;86:824-9.

9 Veith FJ. Lung transplantation in perspective. $N$ Engl f Med 1986;314:1186-7.

10 Hakim M, Wreghitt TG, English TAH, Stovin PGI, Cory-Pearce R, Wallwork J. Significance of donor transmitted disease in cardiac transplantation. Heart Transplantation 1985;4:302-6.

11 Jones DK, Hakim M, Wallwork J, Higenbottam TW. A serious interaction between cyclosporine A and sulphadimidine. Br Med f 1986;292:728-9.

12 Camner P, Strandberg K, Philipson K. Increased mucociliary transport by adrenergic stimulation. Arch Environ Health 1976;31:79-82.
13 Camner P, Strandberg K, Philipson K. Increased transport by cholinergic stimulation. Arch Environ Health 1974;29:220-4.

14 Theodore J, Jamieson SW, Burke CM, et al. Physiologic aspects of human heart-lung transplantation: pulmonary function status of the post-transplanted lung. Chest 1984;86: 349-57.

15 Locke TJ, Griffiths TL, Sutton A, Gibson GJ. Rib cage expansion after median sternotomy Thorax 1987;42:227-8.

16 Braun SR, Birnbuam ML, Chopra PS. Pre- and post-operative pulmonary function abnormalities in coronary artery revascularization surgery. Chest 1978;73:316-20.

17 Dark JH, Patterson FA, Al-Jalahauri AN, Hsu H, Egon T, Cooper JD. Experimental en-bloc double-lung transplantation. Ann Thorac Surg 1986;42:394-8.

18 Caves PK, Stinson EB, Billingham M, Rider AK, Shumway NE. Diagnosis of human cardiac allograft rejection by serial cardiac biopsy. I Thorac Cardiovasc Surg 1973;66:461-4.

19 McGregor CGA, Baldwin JC, Jamieson SW, Billingham ME, Yousen SA. Isolated pulmonary rejection after combined heart and lung transplantation. $\mathcal{F}$ Thorac Cardiovasc Surg 1985;90: rejection

20 Toronto Lung Transplant Group. Unilateral lung transplantation for pulmonary fibrosis. $N$ Engl f Med 1986;314:1140-5.

21 Veith FJ, Montefusco C, Kanholz SL, Mollenkopf FP. Lung transplantation. Heart Transplantation 1983;2:155-64.

22 Nelens JMB, Rebuck AS, Cooper JD, Goldberg M, Halloran PF, Vellend H. Human lung transplantation. Chest $1980 ; 78: 569-73$.

23 Stevens PM, Johnson PC, Bell RL, Beal AC, Jenkins DE. Regional ventilation and perfusion after lung transplantation in patients with emphysema. $N$ Engl f Med 1970;282:245-9.

24 Laurell CB, Eriksson S. The electrophoretic alpha-1-globulin pattern of serum in alpha-1antitrypsin deficiency. Scand $\mathcal{f}$ Clin Lab Invest 1962;15:132-40.

25 George PM, Vissers MCM, Travis J, Winterbourn CC, Carrell RW. A genetically engineered mutant of alpha-1-antitrypsin protects connective tissue from neutrophil damage and may be mutant of alpha-1-antitrypsin protects connective
useful in lung disease. Lancet 1984;ii: 1426-8.

26 Wood RE, Boat TT, Doershuk CF. State of the art; cystic fibrosis. Am Rev Respir Dis 1976;113:833-78.

27 Batten JC. Cystic fibrosis: coming of age. London: Pitman, 1983:367-83.

28 Penketh ARL, Knight RK, Hodson ME, Batten JC. Management of pneumothorax in adults with cystic fibrosis. Thorax 1982;37:850-3.

29 McCarthy M, Rourk MH, Spock A. Bacteraemia in patients with cystic fibrosis. Clin Paediatr 1980;19:746-8.

30 Nelson CA, Caccerame ML, Shwartz RA. Aspergillus and atopy in cystic fibrosis. Am Rev Respir Dis 1979;120:863-5.

31 Myers BD, Ross J, Newton L, Luetocher J, Perbroth M. Cyclosporin-associated chronic nephropathy. N Engl J Med 1984;311:699-705.

(Accepted 15 April 1987)

\title{
Epidemiological assessment of the health and nutrition of Ethiopian refugees in emergency camps in Sudan, 1985
}

\author{
PAUL SHEARS, ANGELA M BERRY, ROSANNE MURPHY, MICHAEL AZIZ NABIL
}

\begin{abstract}
The findings from epidemiological data that were collected from emergency camps for Ethiopian refugees during a mass influx of refugees into Eastern Sudan in 1985 are presented. An overall mortality of 8.9 per 10000 a day was recorded during February
\end{abstract}

Oxfam Health Unit, Oxford

PAUL SHEARS, $M B$, health adviser

United Nations High Commission for Refugees, CH-1211 Geneva ANGELA M BERRY, MSC, nutrition adviser

International Rescue Committee, Gedaref, Sudan

ROSANNE MURPHY, RN, MSC, public health programme coordinator

Commission of Refugees, Khartoum, Sudan

MICHAEL AZIZ NABIL, MD, health coordinator

Correspondence to: Dr P Shears, University Department of Medical Microbiology, Royal Liverpool Hospital, PO Box 147, Liverpool L69 3BX.
1985, and in children under 5 years of age the rate was 22 per 10000 a day. The estimated prevalence of malnutrition (calculated as less than $\mathbf{8 0 \%}$ of the reference weight for height) ranged from $32 \%$ to $52 \%$ among children of preschool age. The principal causes of morbidity and mortality were measles, diarrhoea and dysentery, respiratory infections, and malaria.

The findings suggest that malnutrition and disease increased in these refugees after they arrived in the camps. Epidemiological assessment is essential to help to maintain the health and nutrition of refugees in emergency camps.

\section{Introduction}

Refugee emergencies are characterised by rapid mass migration and subsequent establishment of relief camps that are often large and unplanned. Because of the suddenness of such occurrences there may be insufficient water, food, and shelter in these camps, causing malnutrition and disease in the affected populations. ${ }^{1}$ The earliest medical response is often prompted by emotive media reports and not by epidemiological assessment, resulting in an overemphasis on 